The 16th Economic International Conference

New Challenges and Opportunities for the Economy 4.0, May 7-8th, 2020, Suceava, Romania

\title{
The Consumption Decision in Rural Tourism and Models of Rural Tourism in South Transylvania
}

\author{
Andreea STROE \\ https://doi.org/10.18662/lumproc/ncoe4.0.2020/34
}

How to cite: Stroe, A. (2020). The Consumption Decision in Rural Tourism and Models of Rural Tourism in South Transylvania. In C. Nastase (vol. ed.), Lumen Proceedings: Vol. 13. 16th Economic International Conference NCOE 4.0 2020 (pp. 377-386). Iasi, Romania: LUMEN Publishing House. https://doi.org/10.18662/lumproc/ncoe4.0.2020/34 


\title{
The Consumption Decision in Rural Tourism and Models of Rural Tourism in South Transylvania
}

\author{
Andreea STROE ${ }^{1}$
}

Abstract

\begin{abstract}
Rural tourism has developed in the recent years due to the desire of people to return to their roots and to connect more to nature, away from the crowdedness of the city. Moreover, the fact that a lot of entrepreneurs tend to develop their business in the rural area has lead to an extension of rural services and products. The growth of tourists' interest for visiting rural areas encouraged the residents of inland villages to the new development and new entrepreneurial orientation-tourism. Regardless of the rural area or the country where the rural tourism is practiced, the rural tourist profile tends to have a series of common elements. These include the desire to escape from the city and to integrate into the rural life from the village, the desire to relax, the desire to spend free time with family or any other person in a natural setting and not least, the desire to know the culture of the rural space, with all that it entails. In Romania the rural tourist bases its consumption decision on the intagible and tangible assets that can represent a heritage to be explored, mainly in the perspective of untouch and well preserved traditions at which one can assist. As a result, the tourist who visits these places is supposed to be eager to know the Romanian traditions, to participate in an active way in the life of the village, as it is lived by the members of the community and to enjoy beautiful scenary. So, the purpose of the paper is to analyze the rural consumption decision, the factors that can influence it and to recognize some general tourism models that can be applied in rural area.
\end{abstract}

Keywords: consumption decision; rural tourism; village; rural heritage; tangible assets; intangible assets. 1 National Institute of Economy, Romanian Academy, Bucharest, Romania, email:
stroeandreea@ univnt.ro 


\section{Introduction}

Tourist villages are picturesque rural settlements, well consolidated from an economic, urban and cultural point of view, located in unpolluted environments, conservative of cultural models (customs, inventory of workcrafts, national outfits and gastronomy) and which, beyond political and administrative functions, fulfill, seasonally or permanently, the function of receiving tourists. Tourist villages are generally those rural localities with special natural and anthropic potential, which offer tourists the possibility to return to the natural setting. There are two forms of rural tourism that are put into light, especially in south Transylvania: rural and agrotourism.

Visit to craft workshops, food production areas, agricultural farms, etc. offers the possibility to witness the process of making handicrafts, food preparations (cheeses, sausages, brandies, wines, bakery and pastry products) or non-food, which are then superimposed on the image of the original product. It is is important to mention that rural tourism has special features delimited by the region, country or part of the glob and that is why is difficult to make a clear international delimitation of the rural tourism.

In Finland, rural tourism refers to the rental of peasant houses by tourists or the provision of food and transport services in rural areas. In Hungary, the term "village tourism" is used, indicating that the only activities and services offered in villages are found in this type of tourism, namely accommodation at low prices, involvement in agricultural activities or other types of local activities. In Slovenia the most important form of rural tourism is tourism at family farms, where guests live either in a family of farmers or in guest houses, but visit the farm to dine or simply to explore. In the Netherlands, rural tourism means in particular camping on farms where most of the services offered are related to activities such as: cycling, walking or horse riding. In Portugal, rural tourism has traditionally been associated with staying on farms with the farming family. In Greece, rural tourism means accommodation in traditionally furnished rooms with a traditional breakfast.

In other southern European countries, rural tourism is closely linked to the idea of cheaper holidays, an alternative to resort holidays. In France, for example, several types of rural tourism products are available, such as the famous rural gites (Gîtes de France), guest rooms, camping and caravans, farm stays, equestrian farms, clubs and holiday villages, rural hotels. In some European countries such as Italy, Austria, France or Switzerland, the number of those offering agrotourism services is very high. At present, tourism in the European Union holds $53 \%$ of the market, maintaining its leading role in world tourism, being considered important for economic growth and employment [2] . 
In Romania, at the moment the rural tourist product takes the form of some households or of some settlements that offer primary tourist benefits, offering at the same time with generosity the richness of the values of the Romanian village [3]. The rural activities refers to the display of popular gastronomic products, leisure and animation specific to rural areas, transport by traditional means, pilgrimages to consecrated places of worship, visiting my workshops, etc.

Romanian rural tourism product, represents " a composition of tangible and intangible elements, concentrated in a specific activity and with a specific destination" [4]

\section{Methodology}

Methods such as comparative description, analytical method and graphics have been used. These methods helped to translate data into charts, tables and charts using the Excel program. This paper has three important steps in its development, namely: documentation, analysis of statistical and territorial data research, integration and complex interpretation of information. In the first stage, the documentary we consulted an extensive scientific bibliography which later served as a basis for the present study, providing in particular information regarding the physical-geographic characteristics of the study area. The integration of all information was presented using comparative analysis through complex interpretation of data, statistics and understanding of traditions and customs in Transylvania.

\section{Theoretical Background}

The Transylvanian villages with Saxon fortified churches offer a lively picture of the landscape cultural heritage in southern Transylvania. Saxons colonization was divided in three main parts, corresponding with the inhabited area. These are the areas around three main big cities in Transylvania: Brașov, Sibiu and Bistrița. German colonization in eastern part of Europe implemented planned settlement founding and regulated division of agrarian land. [1]

One peculiarity of transylvanian village related to the tangible patrimony is the special arhitecture of the village with saxon influences. This can influence the consumer decision having into consideration internal factors such as the ethnicity of the tourists, its interest in saxon culture or arhitectural styles, the social backgroud the attitudes and cultural convictions. The Saxon community reflected itself in the village, both the configuration and buildings. The houses are built in strong lines one next to 
each other, but with a wall fence towards the street. The common spaces are generous and large, emphasizing the fortified church. Spatial continuity is understood as functional and aethetic space aggregation, homogenity as formal harmony, stilistic and expresion unity, recognoscibility refers to those particulary elements, unique, unrepetable, the necessity for public functions invests space with community nexus, spatial subordination refers to public space hierarchy and historic shape continuity. One essential characteristic of the settlements from Transylvania was the land division in Flemish plotting system. [6] The fields are situated outside the village. Therefore houses can be arranged in regular rows. This kind of closeness contributed to community spirit development. Housing, yard and field land was divided between the villagers. The forest, the rivers and the grazing were for common use. German colonists brought modern field cultivation methods (triennial rotation) and livestock.[6].Traditional household is set on a rectangular plot, narrow and long. With one or two rooms house, a small shed, barn and stable for cereals and animals, chicken coop, fountain, vegetable garden and fruit orchard. Saxon household is a small self sufficient rural household that even today is adapting to villagers needs [5].

Nonetheless, on the other hand we can refers to the intangible patrimony of transylvanian area which is related to customs and tradition.

Customs and traditions are divided on seasons and tourist decision can be influenced by this intangible elements of patrimony depending on the degree of cultural interes. The most known traditions of spring are: Mărţişorul, The Daffodils festival "blooms" the Braşovian tradition in Şercaia commune, the village of Vad. The Narcissus Festival takes place every year in May in the Dumbrava Vadului Reserve, unique in Europe as a dimension, "Chigala" as a traditional cake made for Easter, the habit of Căluşul is very common in the Transylvanian villages, summer traditions such as: "Harvest House", when the oldest villagers teach the youngest to cut wheat spikes and to bind wheat sheaves, Rusalii; autumn tradition the wretched Sheep is one of the habits of the inhabitants of Bran, symbolizing the end of a pastoral year, the Wailing Sheep is a joyful celebration that tells the arrival of the cold season and the winter traditions such as the casting of evil spirits, the revival of nature and life, traditional songs sang for Christmas, the goat dance is another winter habit, Butea Junilor when The "junkyard" is formed and hosts during the holidays. Then, a week before Christmas, sons of the village bring their homemade dishes for Christmas, Meteleaua, a pagan habit celebrated each year at the winter solstice. On this occasion, the villagers fire fires to drive away the evil, Borița, Sumedru's fire, Farsang is a custom specific to the Saxon community, Santilie, etc. 


\section{Argument of the paper}

The study continues with an analysis of the capacity of touristic accommodation of Mures county integrated in the southern Transylvania region an analysis upon the southern counties of Transylvania, analysis that show us that the number of pensions and agro-touristic pensions are numerous. On counties, the indexes of greater utilization of touristic capacity in which concerns south Transylvania were in Covasna $(46,3 \%)$, Mureş (39,3\%), Cluj (34,7\%), Sibiu (31,7\%).

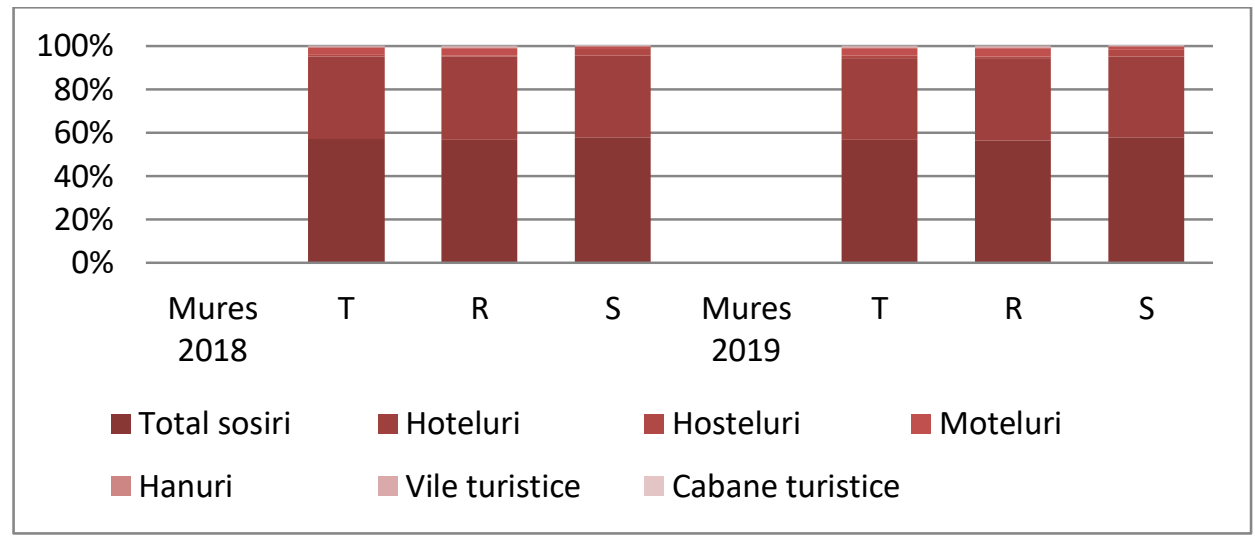

Fig.3 Arrivals of tourists in tourist reception structures with tourist accommodation functions in Mureș county years 2018/2019 [8]

The highest scores are registered in Brașov, Mureș and Sibiu, closely followed by Harghita. The analysis continues with the presentation of numbers for Mureș counties having into consideration that furthermore will follow an analysis of touristic attraction in Saschiz and Idicel Pădure as representants of cultural heritage in the area. So, we can conclude that the number of hotels, touristic villas, cabans is continuously rising from 2018 to 2019 as it can be seen in the charts. As well, the touristic has a favorable evolution in which concerns the total number of arrivals $(T)$ in which concerns the Romanian arrivals as tourists (R) but as well the foreign tourists (S). The number of overnight stays also increased in terms of hotels, hostels and touristic villas. 
Andreea STROE | Lumen Proceedings 13 | NCOE4.0 2020

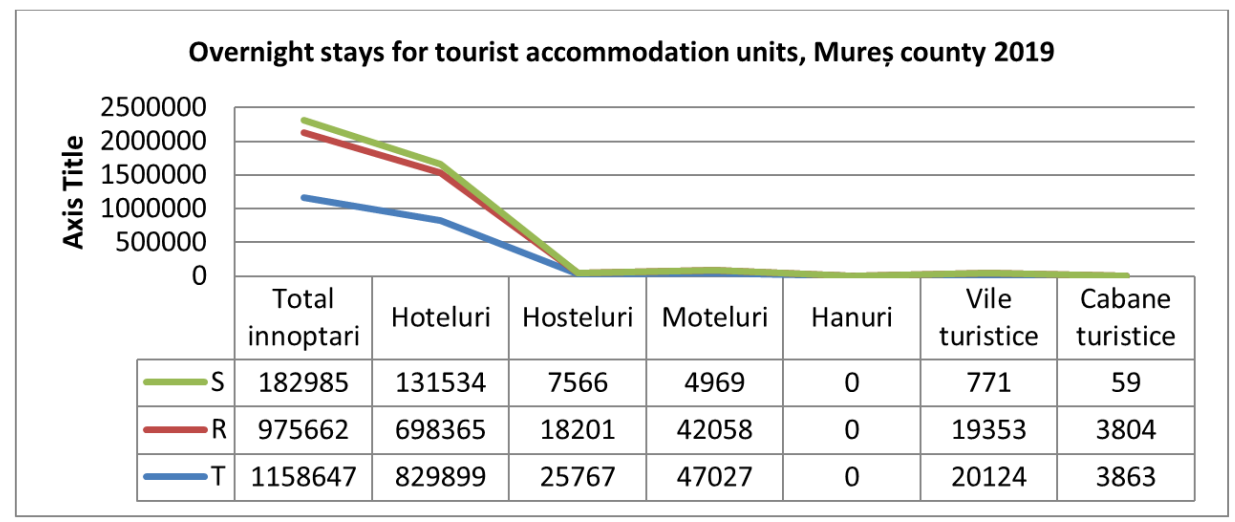

Fig.4 Overnight stays for tourist accommodation units, Mureş county 2019 [8]

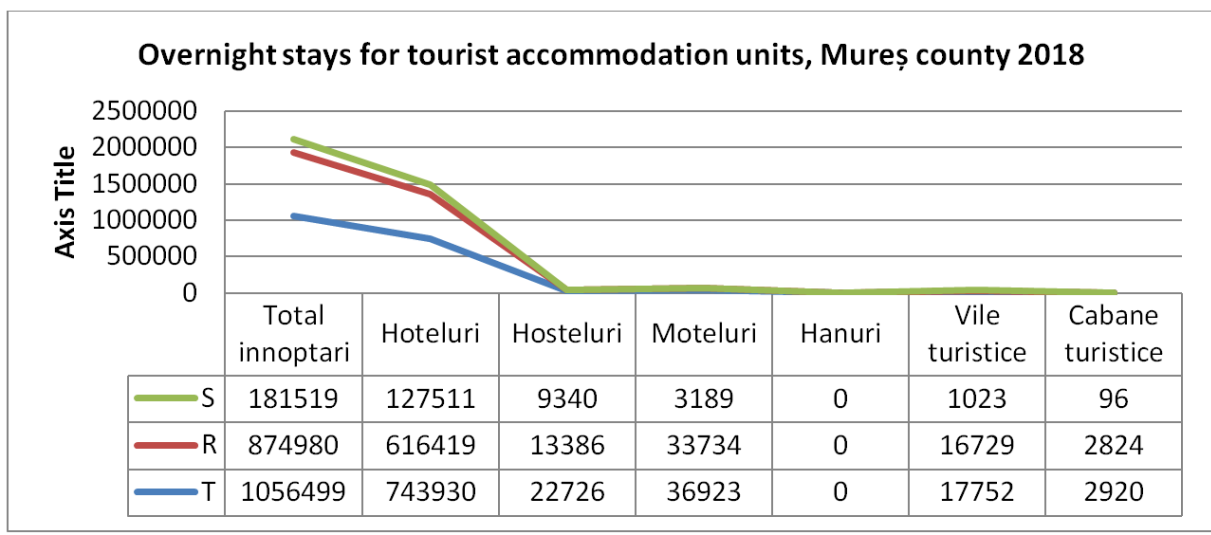

Fig. 5 Overnight stays for tourist accommodation units Mureş county [8]

The existing accommodation structures in Mureş County were, between January 1 and September 30, 2019, the host of a number of 466,832 tourists, with 29,111 more than the corresponding period of 2018, respectively an increase of $6.7 \%$, which made a number of 903,547 overnight stays, with 90,071 more than in the corresponding period of 2018, respectively an increase of $11.1 \%$, and the average length of stay was 1.9 overnight stays / tourist, according to the figures held by the Mureș County Directorate of Statistics. According to the quoted source, the index of net use of accommodation places, between January 1 and September 30, 2019, was $40.6 \%$ of total tourist accommodation structures, increasing by $4.9 \%$ compared to the corresponding period of 2018. According to the country of origin of foreign tourists, the highest shares were held by those from Hungary (20.6\%), Germany ( 12.3\%), Italy (7,3\%), Spain (7.3\%), Republic of Moldova (6.6\%). 


\begin{tabular}{|c|c|}
\hline \multicolumn{2}{|c|}{ Natural Potential } \\
\hline Saschiz & Idicel-Pădure \\
\hline $\begin{array}{l}\text { Landforms: plateau, forests, pastures, } \\
\text { meadows } \\
\text { Particularity, special relief forms called } \\
\text { glimee-mounds, formed by landslides, There } \\
\text { are people who consider these glimes to } \\
\text { be a huge cemetery dating back to ancient } \\
\text { times. }\end{array}$ & $\begin{array}{l}\text { Landforms:submountain landform, at } \\
\text { the foot of the Gurghiului mountains }\end{array}$ \\
\hline $\begin{array}{l}\text { Climate: characteristic to Hills Depression } \\
\text { of Transylvania, the average annual } \\
\text { temperature is } 8.5^{\circ} \mathrm{C} \text {, and the average } \\
\text { annual rainfall is } 598 \mathrm{~mm}\end{array}$ & $\begin{array}{l}\text { Climate specific to submontane and } \\
\text { mountainous areas, with average } \\
\text { annual temperatures of } 4-6 \text { degrees }\end{array}$ \\
\hline $\begin{array}{l}\text { Fauna and flora: } 18 \text { types of natural } \\
\text { habitats, } \\
\text { Euro-Siberian forest-steppe vegetation, } \\
\text { Pannonian forest vegetation, muddy } \\
\text { volcanoes - formations created by } \\
\text { underground natural gas, Cheile } \\
\text { Saschizului }\end{array}$ & $\begin{array}{l}\text { Fauna and flora: mixed forest: oak. } \\
\text { sessile oak, beech, linden, hornbeam, } \\
\text { birch, resin, elm, elm, continued to the } \\
\text { heights with spruce and fir. Meadows } \\
\text { and medicinal plants }\end{array}$ \\
\hline \multicolumn{2}{|c|}{ The anthropic potential } \\
\hline $\begin{array}{l}\text { historical vestiges: fortified church, the } \\
\text { Saxon fortification built between the 14th } \\
\text { and 15th centuries, The Peasant Fortress, } \\
\text { Tower of Evangelical Church }\end{array}$ & $\begin{array}{l}\text { Historical vestiges: The Roman camp } \\
\text { from Brîncovenești, Brâncoveneşti } \\
\text { Medieval Castle: Reformed church } \\
\text { from Brâncoveneşti village, built in } \\
1727 \text {, The village museum from } \\
\text { Brâncovenești; Kuncz Aladár } \\
\text { Memorial Mass, the tomb of the writer } \\
\text { Kemény János; the village museum } \\
\text { from Idicel Pădure, "Laleaua Pestriță" } \\
\text { natural reserve }\end{array}$ \\
\hline $\begin{array}{l}\text { elements of ethnography and folklore: } \\
\text { holidays and balls: Ball of Katarina, } \\
\text { Christmas Ball, Ball of Women in january, } \\
\text { The March of the Gauls } \\
\text { special traditions like Saxon wedding, } \\
\text { Saxon funeral, Saxon Easter, bees, } \\
\text { (gathering between girls that sew, } \\
\text { embroidered, twisted hemp or wool) etc. } \\
\text { Custom of The Neighbourhood= } \\
\text { Rihtogul }\end{array}$ & $\begin{array}{l}\text { Elements of ethnography and folklore: } \\
\text { "the measure of the sheep ", "the feast } \\
\text { of the sheep". and the winter holidays, } \\
\text { La Alei, "Mures Festival" }\end{array}$ \\
\hline $\begin{array}{l}\text { Local holidays: Feast of Rubarbar, } \\
\text { Neighborhood Holidays, Sons of the } \\
\text { Village }\end{array}$ & $\begin{array}{l}\text { Local holidays: Cherry Fair, Maiden } \\
\text { Fair }\end{array}$ \\
\hline
\end{tabular}




\begin{tabular}{|l|l|}
\hline $\begin{array}{l}\text { Local crafts: potery, the ceramics } \\
\text { workshop in Saschiz using sgraffito } \\
\text { technique }\end{array}$ & \\
\hline $\begin{array}{l}\text { The culinary specifics:rubarb jam, special } \\
\text { bread, honey dew from mint or fir }\end{array}$ & $\begin{array}{l}\text { The culinary specifics: jam of Idicel- } \\
\text { Pădure, traditional food }\end{array}$ \\
\hline
\end{tabular}

Source: own source

It can be resumed that the tourist consumption can be developed having into consideration the main advantages of the area: number and value of targets built cultural heritage: rural UNESCO site, category monuments in all component villages of the south Transylvania (there is a Zonal Urban Plan made for the protected area / rural site UNESCO) [7]. Furthermore, rehabilitation works were carried out a fortified evangelical church, several actions took place for the promotion and awareness of preserving the traditional landscape of villages, both by the local administration (making a Good Guide practices for traditional architecture and the Local Heritage Code assumed by HCL) as well as by NGOs: ADEPT Transylvania Foundation, MET, Monumentum Association, existence of a craft workshop of "Saschiz pottery". Another strength of the analyzed region is that there exists socio-cultural infrastructure and religious at the commune level: orthodox churches in each component village, cultural centers, etc. The drawback would be that the buildings with heritage value are in an advanced condition of degradation, which is harmful the general appearance of the commune and in some cases endanger the safety of passers-by (ex: former German school in the center of Saschiz). On the other side, intangible patrimony identified (local traditions and customs) are less promoted compared to build cultural heritage, lack of necessary construction materials adequate restoration of traditional houses.

Other axis that can be used in order to highten the touristic consumption refer to the existence of protected areas: Natura sites 2000 SCI and SPA, signaling the tourist objectives from joint project carried out by the EAFRD project, connecting the commune to the bike path made by the ADEPT foundation on the route Viscri - Sighisoara, the possibility to rent bicycles to tourists for practicing cycle tourism,, NGOs active in the area for tourism promotion, the existence of local brands (eg Casa de pe Deal, Grandma's Cellar), zonal tourist brand: Târnava Mare, inclusion of the commune in the potential ecotourism destination Transylvania Hills. The implication of the local administration and locan entrepreneurs to European and national project in order to include Saschiz area or Idice-Pădure area in contact with touristic development opportunities is another important point. Saschiz takes part at "Green infrastructure - Promoting an integrated 
sustainable development of the commune - part of the Natura 2000 sites Târnava Mare and Hârtibaciului Plateau, by taking care of the existing potential and by improving the quality of life of the inhabitants of Saschiz commune". Idicel-Pădure integrates into the Strategy of development of Mureș county.

\section{Conclusions}

The main directions that where outlined regarding the cultural heritage were ethnographic and folklore tourist villages, tourist villages of artistic and craftsmanship, landscape tourist villages, that focus on the idea that multiculturalism is an undeniable reality and value in both cultural spaces formed in countries with a large contribution of immigrants that can lead to multiple inputs and outputs regarding innovation and the methods in which the touristic potential of a rural area can be valorized.

At the extremes, we can find a mono-cultural model of visiting the cultural heritage, that implies knowing tradition in one place and making the accommodation in a nearby city, for example you visit the surroundings of Sibiu but you choose to make the accommodation in a hotel in Sibiu, so you will "migrate" in order to make the heritage consumption in the near villages knowing the intangible patrimony as customs, tradition, food in a different place, so you will have a radial consumption model of rural tourism based on rural heritage. At the other extreme, it can be found a more centered model of mono-cultural rural entrepreneurship that has into consideration the village-hotel concept that emphases the collaboration between all inhabitant entrepreneurs of the location that provides separately accommodation, food, culture consumption.

The current situation of the transylvanian village is realted to depopulation, local population disappearance or decrease is due to expatriation, urban migration or aging, degradation, social and economic decline affects traditional built fabric. After the village community fell apart, the decay of the settlements was implicit. Saxon villages are resource for food, shelter and craft, but also exhibit a model of living, hence a certain lifestyle that involves an equilibrium between human and nature. The advantage is that sociologists notice a social phenomenon emerging in the rural areas. People are moving from crowded cities to villages. Not only the survival need determines people to move, but also another view upon life. People that are moving to the rural areas are educated and are determined by the will to change their way of living and the environment. In 2011, about 16.000 Romanians moved to the rural areas. As fas as we analyzed the 
principal attraction in the studied area (Mureș district) are intangible assets in cultural heritage, ethnografic traditions, customs follwed by the beautiful scenary, landscape which represents coordinates for leaisure tourism. But this can represent the premises as a future reaserch regarding the typology of tourism consumption in different country regions.

\section{Acknowledgment}

"This work was supported by a grant of the Romanian Ministery of Research and Innovation, CCCDI-UEFISCDI, project number PN-III-P11.2-PCCDI-2017-0884/56 PDDCI/03.04.2018., within PNCDI III".

\section{References}

[1]. Cocean P, Vlăsceanu G, Negoescu B. Geografia generală a turismului. Bucureşti: Editura Meteor Press; 2002. 221 p.

[2]. Dorobanţu MR. Forme de dezvoltare şi promovare a turismului rural în spațiul Uniunii Europene. Analele Universităţii „Constantin Brâncuşi” din Târgu Jiu, UCB; 2011, 4: 80-84.

[3]. Firoiu D. Economia turismului şi amenajarea turistică a teritoriului, Bucureşti: Editura Sylvi; 2002. 118 p.

[4]. Medlik, H. "The product formulation in tourism". AIEST, Tourisme et marketing;1995, 13.

[5]. Nistoreanu P. (coord.). Managementul durabil al comunităţilor rurale şi turismul. Bucureşti: Editura ASE; 2010. 43 p.

[6]. Opincariu DS, Voinea AE. Cultural Identity in Saxon Rural Space of Transylvania, Acta Technica Napocensis: Civil Engineering \& Architecture.2015; 4 (58).

[7]. Plesoianu D-M, Grecu E, Popescu A. The heritage of traditions and tourism facilities in Transilvania, Romania, Scientific Papers Series Management, Economic Engineering in Agriculture and Rural Development 2018; 18 (1).

[8]. Institutul naţional de statistică. Available from: https://insse.ro/ 